\title{
Chipped Glass, Ceramics, and Axe Handles
}

\section{Claude McCrocklin}

Unknown

Follow this and additional works at: https://scholarworks.sfasu.edu/ita

Part of the American Material Culture Commons, Archaeological Anthropology Commons, Environmental Studies Commons, Other American Studies Commons, Other Arts and Humanities Commons, Other History of Art, Architecture, and Archaeology Commons, and the United States History Commons

Tell us how this article helped you.

This Article is brought to you for free and open access by the Center for Regional Heritage Research at SFA ScholarWorks. It has been accepted for inclusion in Index of Texas Archaeology: Open Access Gray Literature from the Lone Star State by an authorized editor of SFA ScholarWorks. For more information, please contact cdsscholarworks@sfasu.edu. 


\section{Chipped Glass, Ceramics, and Axe Handles}

Creative Commons License

(c) (i) (8)

This work is licensed under a Creative Commons Attribution-NonCommercial 4.0 International License 


\section{CHIPPED GLASS, CERAMICS, AND AXE HANDLES}

by

Claude McCrocklin

INTRODUCTION

This is a brief paper on chipped glass and Euro-American ceramics found on Historic Indian sites in the ARK-LA-TEX region. These tools have long puzzled archaeologists as to their use, and still do to some extent today; hopefully this paper will clarify matters. Chipped and pressure-flaked glass was probably used differently from chipped ceramic tools, since the latter were softer and not as sharp as the bottle glass. As most of the chipped tools found were made of glass, this paper will deal primarily with them.

\section{ARTIFACT DESCRIPTIONS}

Most of the chipped glass tools that I have found are made from bottle glass, usually glass from wine bottles (Figure 1-4). The one exception was an unusually large tool from the base of a lamp. This piece was carefully chipped all around the base, the flared middle section, and the neck. It was found on an early 20th century Caddo Adais site. All of the other chipped bottle glass tools have been found on Historic Indian sites dating from about $1790-1835$.

In the case of the bottle glass tools, all parts of the bottle were used: the neck, sides, and bottom. The area most often used was the bottom when parts of the side of the bottle were still attached. Chipping varied from the removal of medium to large chips to the removal of small pressure flakes. Sometimes both pressure flakes and larger chips were removed to produce a very sharp, serrated cutting edge.

Only the side pieces of the bottle were bifacially chipped; these resemble prehistoric stone scrapers or knives. In fact, on the Battle Lake Delaware Indian site (3LA185) in Southwest Arkansas, a stone bifacial scraper was found with chipped ceramic and glass 

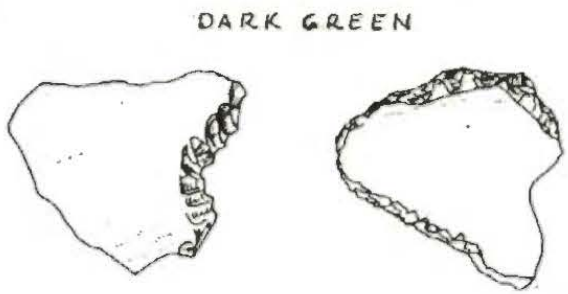

CLEAR

DARK BROWN
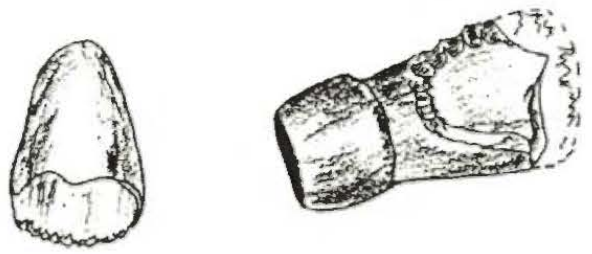

DARK GREEN - ROLLEO LIP
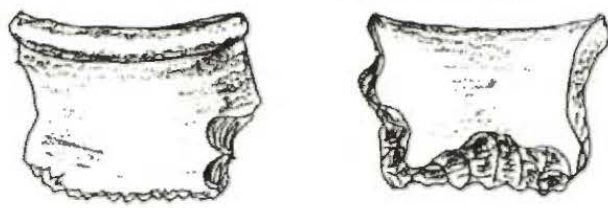

FRONT

BACK

Figure 1. Chipped Bottle Glass from 16CD209.
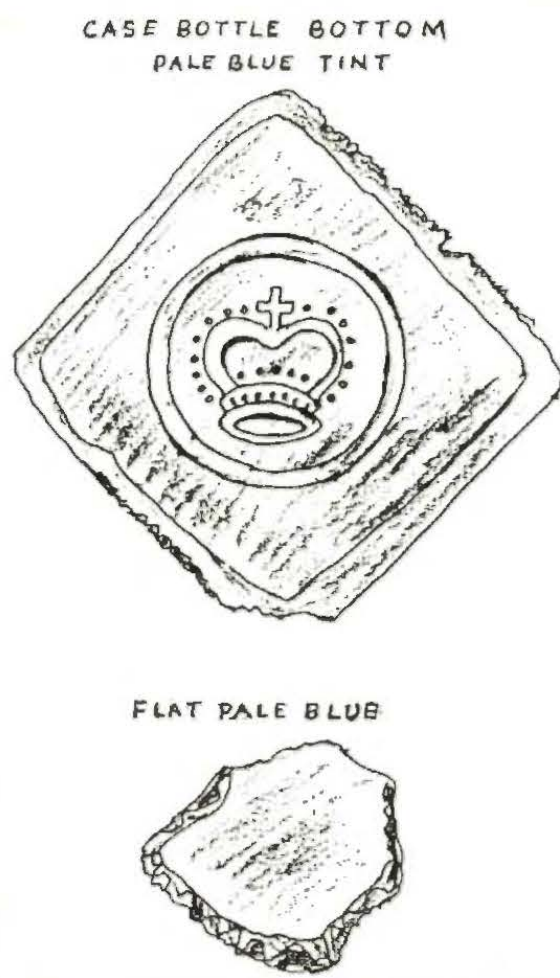

Figure 2. Chipped and Flaked Bottle Glass from 16CD209. 


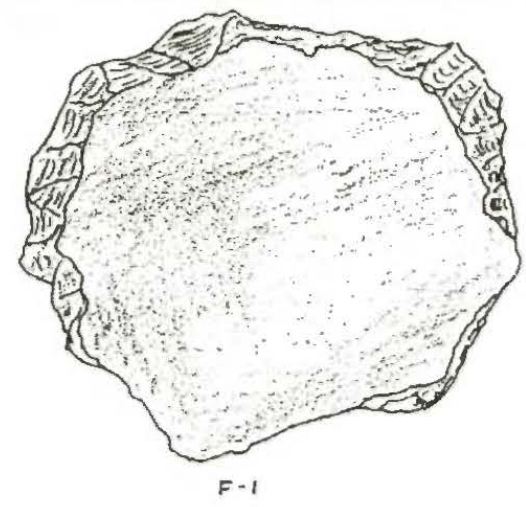

स्तCM

NOTE: STONE SCRAPER, OR KNIFE FOUND WITH THE CHIPPED CERAMIC SHERD, UTENSILS AND HORSE BONE

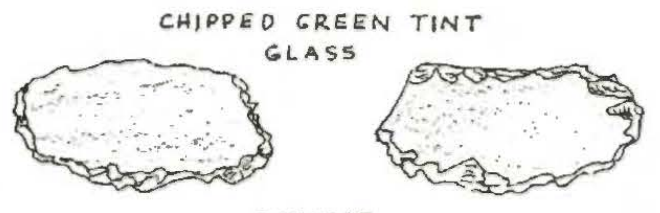

SURFACE

Figure 3. Chipped Stone and Glass tools from 3LA185.

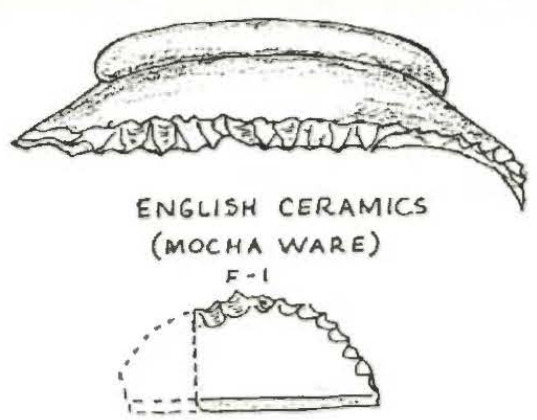

DARK GREEN WINE BOTTLE GLASS
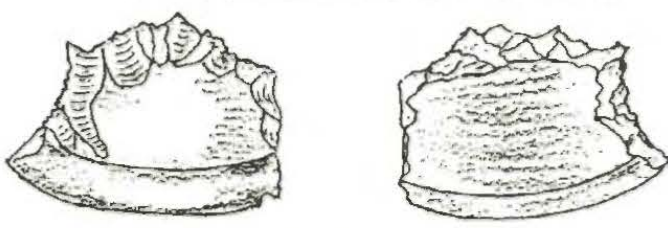

FRONT $F-3$

BACK
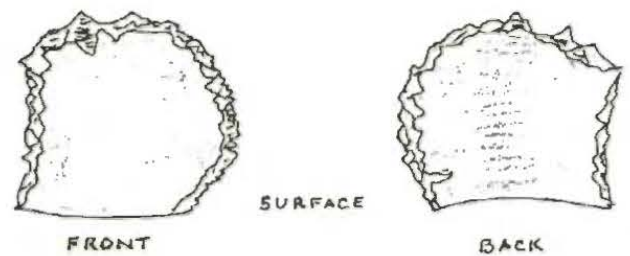

SCALE

Figure 4. Chipped Bottle Glass and Ceramic Tools from 3LA185. 
scraping tools (see Figure 3 and 4). These were found in a trash pit with horse bones, metal knives, pans, and Euro-American ceramics.

Chipped Euro-American ceramic tools were most often made from bowl or cup bottoms with the sides still attached (Figure 5 and 6 ). Curiously, on most examples the rim base of the bottom was chipped as well as the sides. Flat parts of plates were used, but not as frequently. On these pieces, the bottom rim, or the base, of the plate was left attached, presumably as a grip or handhold. This suggests that what was worked on was wet or greasy. Also, most of the chipped tools were made from bottles, bowls, and cups with curved edges. This meant that whatever the tool was used for a curved edge worked the best.

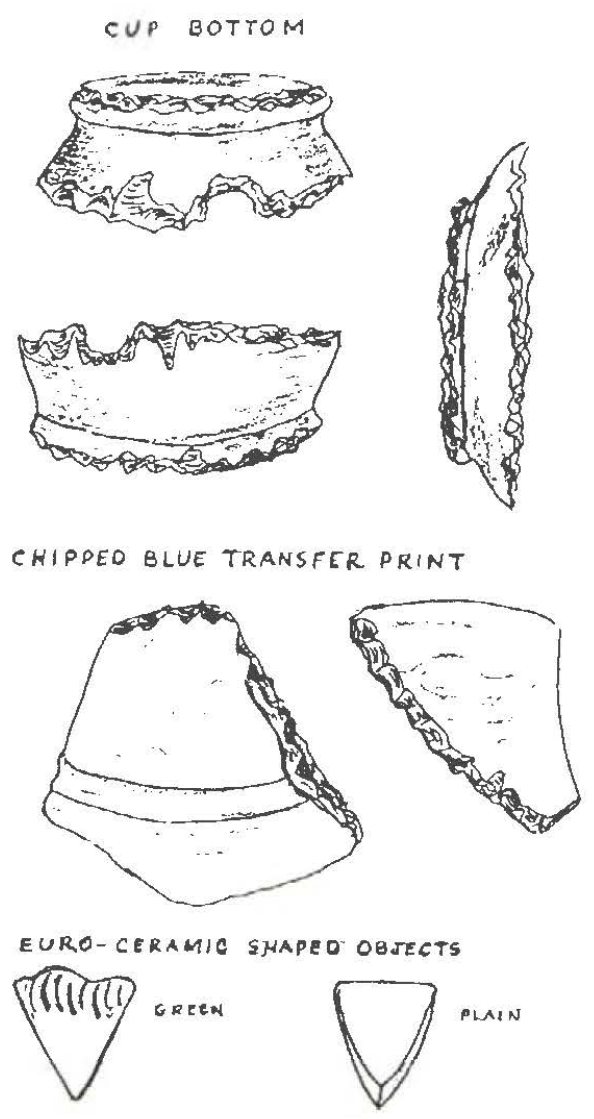

Figure 5. Chipped and flakes Furo-American ceramics from 16CD209. 


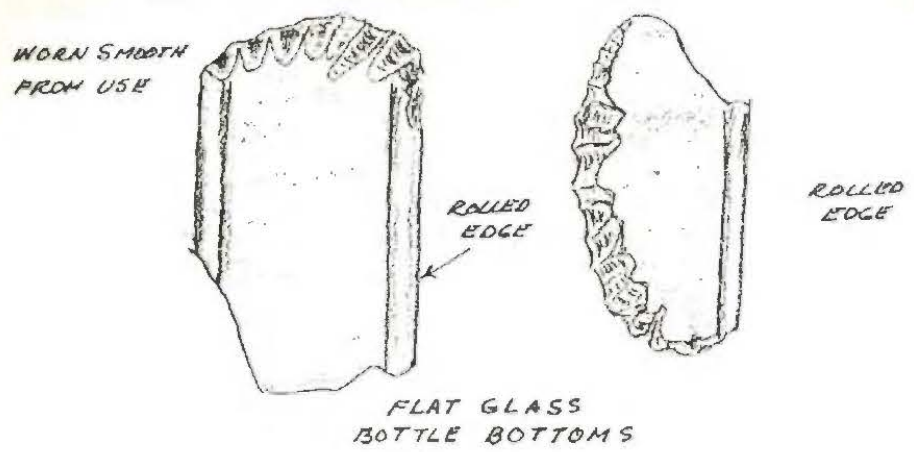

CWIPPED CERAMICS

CRACKEYY BOTTLE SHERO

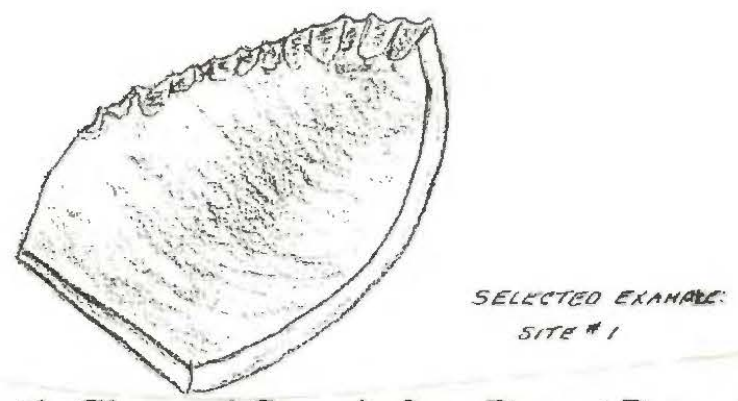

Figure 6. Chipped Bottle Glass and Ceramic from Dupont Bayou Site.

\section{POSSIBLE USE OF CHIPPED CERAMICS AND BOTTLE GLASS}

The most plausible and best answer regarding the use of chipped ceramic and glass tools comes from two older Caddo Indians, one in Oklahoma (Phil Newkumet) and a Caddo Adais in Louisiana (Carter Moore). They said that when they were young, they used chipped ceramics and glass to scrape the hair off of animal hides. The chipped edges caught the hair and pulled or cut it off. These two Caddo men live 500 miles apart, and neither knew each other, yet they both provided the same explanation on the use of these tools; this gives credence to their common explanation.

One thing is certain: chipped glass and ceramic tools were not used to work wood. As a boy growing up on a farm in Southwest Arkansas during the 1930s, I helped my grandfather make axe handles and other wooden implements used on the family farm. We used glass to smooth and finish the handle after it was worked down to size with an axe and drawing knife. But we always used flat, straight-edged window pane glass. If the 
scraping edge was "nicked," or chipped, it was discarded, because it would make grooves on the wooden handle. This is easily illustrated by taking a piece of chipped and edged glass and scraping a piece of wood. It will be necessary to also use a flat piece of window pane glass to smooth out the grooves.

\section{CONCLUSION}

Chipped glass and ceramic tools have been found on all 38 Historic Indian sites that I have found and tested over the years in the ARK-LA-TEX region. These sites had been occupied by Coushatta, Cherokee, Delaware, and Caddo groups. They all made and used these tools. Thus, in my opinion chipped glass and ceramic tools are of Historic Indian origin, and their discovery helps to identify the sites where they lived. Recently, however, Dr. H. F. Gregory found several chipped glass tools on an Anglo-American site (dated 1890-1900) in Louisiana in the Williamette Forest along Dugdemona Bayou. This is the first report of such tools on a non-Indian site, and may indicate that Anglo-American settlers learned the use of these tools from Indians (Dr. H.F. Gregory, August 1993 personal communication).

\section{NOTE}

Other chipped glass and ceramic tools from sites in Texas, Arkansas, and Louisiana are in collections in Austin, Texas, Magnolia, Arkansas, and in the Caddo-Pine Island Museum in Oil City, Louisiana. 